\title{
STABILITAS STATIS KAPAL POLE AND LINE KM ALDEIS DI PELABUHAN PERIKANAN AERTEMBAGA BITUNG SULAWESI UTARA
}

\author{
Fransisco P.T. Pangalila \\ Program Studi Pemanfaatan Sumberdaya Perikanan, \\ Fakultas Perikanan dan IImu Kelautan. UNSRAT. Manado 95115.
}

\begin{abstract}
The uncertainty of ocean conditions, such as currents and waves, affects the maneuver ability and stability of vessel on the water. For this reason, a fishing vessel should fulfil specific prerequisites, such as strong vessel construction, good stability to extreme oceanic conditions, good maneuver ability, and thrust.

"Aldeis" boat has a dimension of $15.50 \mathrm{~m}$ long, $2.80 \mathrm{~m}$ wide, and $1.10 \mathrm{~m}$ deep. Average ratio of those parameters was 5.50 for $L / B, 13.05$ for $L / D$ and 2.37 for $B / D$, rspectively. The coefficient values of the boat shape were $\mathrm{Cb}=0.54$ for $\mathrm{Cb}, \mathrm{Cp}=0.73$ for $C p, 0.74$ for $C^{\otimes}$ and 0.79 for $C 3$, respectively.

The boat possessed a maximum shakes to 140 of the boat slant when the righting arm was at $0.20 \mathrm{~m}$ of the center point.
\end{abstract}

Keywords: Aldeis boat, stability, dimension, shake.

\section{PENDAHULUAN}

Kapal adalah kendaraan air dengan bentuk dan jenis apapun, yang digerakkan dengan tenaga mekanik, tenaga angin atau ditunda, termasuk kendaraan yang berdaya dukung dinamis, kendaraan di bawah permukaan air, serta alat apung dan bangunan terapung yang tidak berpindah-pindah $(U \mathrm{U}$ RI No. 21 Tahun 1992 tentang Pelayaran).

Ayodhyoa (1972) menyatakan bahwa apabila kita akan membuat kapal guna keperluan pengembangan usaha penangkapan ikan tentu saja terlebith dahulu harus diperhatikan berbagai persyaratan seperti pemilihan jenis kapal sesuai dengan jenis usaha (pancing tangan, pukat udang, pukat cincin, pole and line dan lain-lain), kemudian menentukan besarnya, bentuk, ukuran utama, kecepatan dan lain-lain. Selanjutnya Ayodhyoa júga menyatakan bahwa bentuk kapal ada yang langsing, montok dan gemuk. Koefisien yang menggambarkan keadaan ini disebut koefisien balok $(\mathrm{Cb})$ koefisien garis air $(\mathrm{Cw})$, koefisien perismatik $(\mathrm{Cp})$ dan koefisien tengah kapal $\left(\mathrm{C}_{\otimes}\right)$.

Kondisi alam suatu daerah penangkapan tidaklah menentu, seperti terjadinya gelombang maupun arus yang datang sehingga dapat mempengaruhi olah gerak dan stabilitas kapal. Untuk itu, kapal perikanan harus memiliki dan memenuhi persyaratan khusus, seperti konstruksi ba- ngunan kapal yang kokoh dan tahan terhadap kondisi laut yang paling buruk sekalipun, pamun tetap memiliki kemampuan olà gerak yang baik serta daya dorong rang besar.

Inclining Experiment atau yang disetout juga pengujian kemiringan adalah praktek investigasi stabilitas dalam menyelesaikan pembuatan kapal untuk semua kapal baru (Hind,1967). Objek dari pengujian kemiringan ini sebagaimana dikenal adalah posisi pusat gravitasi dan menjadi alasan untuk sebuah praktek investigasi karena posisi $G$ tidak dapat dihitung dengan beberapa derajat dari kemampuan gambar desain. Selanjutnya, dijelaskan bahwa dari poin yang ada dalam pengerjaan kapal, tujuan utama suatu pengujian kemiringan adalah nilai tertinggi dari titik metacentris. Juga, di posisi pusat gravitasi untuk nilai yang akurat dibutuhkan untuk membuat kapal tetap dalam keadaan stabil pada saat pengoperasian. Oleh karena itu, pengujian kemiringan ditampilkan untuk memperoleh jarak vertikal dari titik $G$ di atas titik $\mathrm{K}$ secara akurat ketika kapal dalam keadaan tenang/stabil.

Menurut Hind (1967), keselamatan pelayaran suatu kapal lebih banyak ditentukan oleh stabilitas. Stabilitas kapal adalah kemampuan kapal tersebut untuk kembali ke posisi semula setelah mengalami gayagaya tarik dari luar maupun dari dalam 


\section{Stabilitas Statis Kapal Pole And Line}

kapal yang menyebabkan kapal itu miring. Selanjutnya, dijelaskan bahwa pada suatu benda yang mengapung diam di permukaan air terdapat dua gaya utama yang sama besar dan bekerja berlawanan arah pada sumbu vertikal, yaitu gaya berat $\mathrm{G}$ (Center of Gravity) dan gaya apung B (Center of Buoyancy).

Lester (1985) menyatakan bahwa terdapat 3 titik yang memegang peranan penting dalam peninjauan stabilitas suatu kapal yaitu titik G, B dan M. Menurut Kok (1983), titik berat $\mathrm{G}$ adalah titik resultan gaya berat seluruh bagian kapal termasuk semua isi yang berada di dalamnya yang menekan ke bawah; titik apung $B$ adalah titik berat geometris bagian kapal yang terbenam dalam air yang menekan ke atas dan titik $M$ (Metacenter) adalah tinggi sudut inklinasi dari lunas kapal serta titik pusat garis yang bekerja gaya apung dan gaya berat. Gaya-gaya yang menyebabkan terjadinya stabilitas adalah gaya berat $G$ yang besarnya sama dengan pemindahan air $D$ (displacement), dan gaya apung yang bekerja pada B yang sama juga besarnya dengan pemindahan air $D$, seperti dikemukakan dalam hukum Archimedes. Bila $G$ dan B letaknya tidak vertikal segaris, maka akan terjadi momen kapal bergerak sesuai arah momen.

Berdasarkan posisi relatif titik $M$ terhadap G, maka Muckle (1978) menyatakan sebagai berikut:

1. Apabila titik $G$ berada dibawah titik $M$, maka momen penedak (Righting moment, $\mathrm{RM}=\Delta \cdot \mathrm{GZ}$, sedangkan $\mathrm{GZ}=\mathrm{GM}$ $\operatorname{Sin} \theta)$ bernilai positif karena lengan penegak (GZ) bernilai positif. Momen penegak ini sanggup mengembalikan kapal ke posísi tegak semula. Stabilitas yang demikian disebut stabilitas positif (stabil)

2. Apabila titik $G$ dan $M$ berimpit, maka momen penegak RM akan sama dengan nol karena tidak terbentuk lengan penegak $(\mathrm{GZ}=0)$ sehingga $\mathrm{RM}=0$. Ini berarti apabila kapal sengat (olengan cepat), maka kapal tersebut akan tetap sengat sebab tidak ada lengan penegak. Stabilitas yang demikian disebut stabilitas netral.

3. Apabila titik $G$ berada di atas titik $M$, maka momen penegak RM bernilai negatif karena lengan $G Z$ bernilai negatif. Momen penegak ini tidak mampu mengembalikan kapal ke posisi tegak semula, malah membantu memiringkan kapal dan kemungkinan kapal terbalik. Stabilitas yang demikian disebut stabilitas negatif (labil).

Stabilitas adalah kemampuan kapal untuk kembali ke posisi semula sesudah miring akibat bekerjanya gaya-gaya terhadap kapal (Hind, 1967). Sebaliknya Edward dan Robert (1980) menyatakan bahwa stabilitas adalah kombinasi antara ukuran yang cocok dan pembagian berat muatan yang memungkinkan kapal untuk mengikuti kekuatan angin dan gelombang, serta selalu dapat kembali tegak dan seimbang lagi atau kecenderungan kapal yang bergoyang ke kiri dan ke kanan untuk kembali ke posisi tegak. Selanjufnya, Handryanto (1982) menambahkan bahwa stabilitas adalah kehendak dari kapal untuk kembali ke keadaan semula apabila kapal tersebut mendapat tenaga atau gaya dari luar.

Stabilitas statis adalah kecenderüngan kembalinya kapal ke posisi semula setelah kapal cenderung dimiringkan pada saat kapal dalam keadaan diam. Ini adalah bukti bahwa di bawah kondisi biasa kapal tidak selalu dalam keadaan lurus. Kapal secara terus menerus dipaksa keluar dari posisi lurusnya oleh gaya-gaya dari luar seperti angin dan gelombang. Sangatlah penting bahwa kapal harus memiliki kualitas tertentu sehingga sudut miring yang terjadi tidak mempangaruhi keamanannya.

Kapal dikatakan stabil jika pada saat kapal dimiringkan, kapal cenderung kembali ke posisi semula dengan periode olengan relatif pendek. Kapal dikatakan tidak stabil jika pada saat dimiringkan lambat kembali ke posisi semula, periode olengan kapal relatif panjang untuk kembali ke keadaan semula. Kapal dikatakan dalam keadaan netral jika, pada saat kapal dimiringkan tidak menjauh dari posisi semula. (Attwood dan Pengelly, 1967).

Masyarakat nelayan di Sulawesi Utara umumnya menggunakan kapal tipe lambut untuk melakukan penangkapan ikan cakalang (Katsuwonus pelamis). Kapal tersebut umumnya dibuat oleh pengrajin tradisional berdasarkan keahlian alami atau pengalaman turun-temurun, tanpa perencana- 
an gambar dan kurang aplikasi teknis yang sesuai dengan teori perkapalan. Kurangnya pengontrolan bagi nelayan dan pembuat kapal mengenai stabil tidaknya kapal adalah salah satu penyebab operasi penangkapan tidak dapat berjalan dengan baik. Dalam pembuatan kapal, para pengrajin tidak memperhatikan hubungan antara besar kapal, tenaga pendorong dan kecepatan kapal, sehingga sering terjadi benturan antara keinginan untuk membuat kapal menjadi cepat tetapi kapal tersebut oleng dan tidak stabil, oleh sebab itu perlu dilakukan penelitian mengenai olengan bebas kapal ikan tipe Pole and line.

Berdasarkan permasalahan di atas, penelitian ditujukan untuk:

1. Mengetahui ukuran-ukuran utama pada kapal pole and line kecil yang berpangkalan di Pelabuhan Perikanan Bitung.

2. Menggambar rancangan garis kapal pole and line kecil dari ukuran yang sudah ada.

3. Mengkaji stabilitas statis dari kapal sampel di lapangan sebagai bahan informasi guna keselamatan orang di atas kapal.

Hasil dari penelitian ini diharapkan dapat memberikan manfaat bagi masyarakat nelayan, pengusaha dan peneliti, antard lain:

1. Sebagai bahan informasi bagŕnelayan dan pengusaha perikanan tentang pentingnya membuat kapal ikan yang mempunyai stabilitas yang baik.

2. Sebagai bahan masukkan yang penting bagi pengembangan Hmu dan teknologi perikanan khususnya yang berhubungan dengan kapal ikan.

3. Sebagai bahan pemikiran dasar bagi masyarakat nelayan bahwa kelayakan kapal berrärti keselamatan dan kesejahteraan hidup.

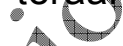

\section{e) METODE PENELITIAN}

Penelitian ini dilakukan pada kapal pole and line KM Aldeis di kota Bitung Sulawesi Utara, tepatnya di lokasi Pelabuhan Perikanan Aertembaga. Selanjutnya data diolah di Laboratorium Kepelautan Fakultas Perikanan dan IImu Kelautan Universitas Sam Ratulangi.
Teknik pengumpulan data dilakukan melalui pengamatan dan pengukuran secara langsung di lapangan, serta wawancara untuk memperoleh data primer dan pengutipan informasi dari beberapa tulisan ilmiah sesuai dengan topik penelitian untuk memperoleh data sekunder.

1. Pengukuran ukuran utama kapal

a. $\mathrm{L}_{\mathrm{OA}}$ (Length Over All), panjang seluruh kapal yang diukur dari bagian paling ujung buritan hingga bagian paling ujung haluan.

b. BM (Breadth Moulded), tébar kapal yang diukur mulai dari sisi luar kapal yang satu ke sisi lainnya.

c. D (Depth), dalam atau tinggi kapal yang diukur mulai dari dek terendah hingga ke baglan badan kapal terbawah.

d. $L_{W L}$ (Length Water Line), panjang garis air.

e. d (draf), dalam sarat kapal yang diukur dari $L_{W L}$ (kondisi kapal kosong) hingga ke bawah kapal terbawah atáu lunas bagian atas.

Penggambaran lambung kapal Untuk menggambarkan lambung kapal digunakan teknik pengukuran dengan pantograf bagi kapal yang berada di atas air.

3. Penentuan olengan bebas kapal

Aturan-aturan untuk mengukur GM dapat dilakukan dengan menggunakan percobaan momen sistem pengujian kemiringan yaitu:

a) Kapal diusahakan dalam keadaan diam atau dapat juga dengan cara mengikat kapal agar tidak oleng karena pengaruh ombak.

b) Menyiapkan beban yang telah diketahui beratnya.

c) Mengukur panjang lengan kapal pada bagian tengah kapal paling lebar.

d) Menempatkan klinometer pada bagian tengah kapal yang paling lebar.

e) Meletakkan beban pada bagian pinggir kapal yang paling lebar, kemudian sudut yang dibentuk pada klinometer dicatat.

f) Ketika semua alat sudah diset, kemudian berat 6 orang yang akan melakukan gerakan untuk mengolengkan kapal ditimbang. 


\section{Stabilitas Statis Kapal Pole And Line}

g) Melakukan penambahan beban sebanyak tiga kali dimana dari setiap beban dilakukan tiga kali pengulangan.

h) Enam orang tersebut berdiri di tepi kapal untuk membentuk sudut, lalu berlari dari tepi lebar kapal yang satu ke tepi lebar kapal yang lainnya, pengulangan dilakukan selama 3 kali, lalu keenam orang diam di bagian tengah kapal.

i) Setelah kapal melakukan gerak oleng angka-angka yang ditunjukkan oleh bandul ketika benang bandul bergerak di samping busur dibaca skalanya.

\section{Analisis Data}

1. Menghitung Volume kapal

Volume kapal dihitung dengan menggunakan aturan trapesium, seperti yang dikemukakan oleh Namura dan Yamazaki (1977) dengan rumus:

$$
\begin{aligned}
& A=\frac{h}{2}\left(Y_{1}+2 Y_{2}+2 Y_{3}+\ldots+2 Y_{m-1}+Y_{m}\right) \\
& \nabla=\frac{H}{2}\left(A_{1}+2 A_{2}+2 A_{3}+\ldots+2 A_{n-1}+A_{n}\right)
\end{aligned}
$$

3. Pengukuran dan perhitungan stabilitas kapal

Pengukuran dilakukan dengan metode momen yaitu menggunakan beban yang diletakkan pada salah satu sisi kapal yang kemudian dilakukan pembacaaan terhadap setiap perubahan yang terjadi.

Untuk mengetahui olengan bebas digunakan koefisien froude (Dalzell, 1978), yang dapat menghitung rolling dumping yaitu kurva yang menggambarkan besar olengan yang terjadi pada kapal.

$$
\begin{aligned}
\text { dimana: } & \\
\Delta \phi & =\text { rolling dumping } \\
\mathrm{a}, \mathrm{b} & =\text { koefisien extinsi }
\end{aligned}
$$$$
\Delta \phi=a \phi^{\prime} n+b \phi^{\prime} n^{2}
$$

Untuk menentukan curve extinction (Koefisien $\mathrm{N}$ ) digunakan:

$$
\Delta \phi^{\prime}=\frac{\Delta \phi}{\left(\phi_{i}+\phi_{i+1)} / 2\right.}
$$

Hasil perhitungan selanjutnya di petakan dalam Kurva stabilitas statis dengan menggunakan rumus.

$$
\begin{aligned}
\mathrm{A} & =\text { Luas bidang section } \\
\mathrm{h} & =\text { jarak antar garis di section } \\
\mathrm{Y}_{\mathrm{i}} & =\text { tinggi garis di section } \\
\nabla & =\text { Volume Kapal }\left(\mathrm{m}^{3}\right) \\
\mathrm{H} & =\text { Jarak antara bidang }(\mathrm{m}) \\
\mathrm{A}_{\mathrm{i}} & =\text { Luas bidang ke-i }\left(\mathrm{m}^{2}\right) \\
\mathrm{i} & =1,2,3, \ldots \mathrm{n} \text { (jumlah Bidang) }
\end{aligned}
$$

\author{
$\times$
}

2. Koefisien bentuk kapal

Untuk menghitung nitail dari masingmasing koefisien bentuk, maka digunakan rumus yang dikemukakan oleh Nomura dan Yamazaki (1977) sebagai berikut:

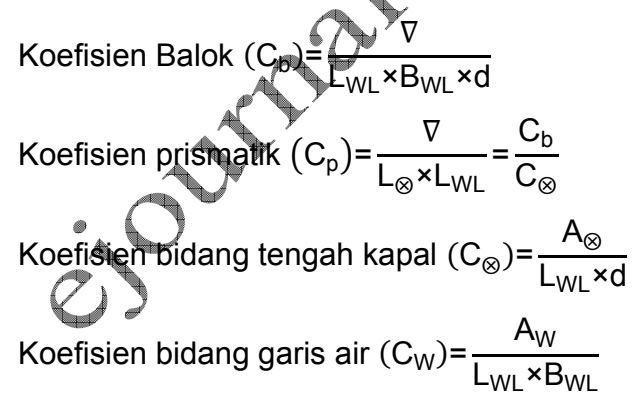

dimana:

$\mathrm{L}_{W L}=$ panjang kapal pada garis air $(\mathrm{m})$

$B_{W L}=$ lebar kapal pada garis air $(m)$

$\mathrm{d}=\operatorname{draft}(\mathrm{m})$

$A_{w}=$ luas bidang garis tengah air $\left(\mathrm{m}^{2}\right)$

$A_{\otimes}=$ luas bidang penampang tengah $\left(\mathrm{m}^{2}\right)$

$\nabla=$ volume $\left(\mathrm{m}^{3}\right)$

$$
\int_{0}^{\phi} \operatorname{m} \phi \mathrm{d} \phi=\int_{0}^{\phi} w \cdot \overline{\mathrm{GZ}} \mathrm{d} \phi=\int_{0}^{\phi} \Delta \cdot \overline{\mathrm{GZ}} \mathrm{d} \phi
$$

dimana:

$$
\begin{aligned}
\mathrm{m}^{\phi} & =\text { momen penegak } \\
\frac{\mathrm{d}}{\overline{\mathrm{GZ}}} & =\text { sudut tambahan } \\
& =\text { lengan penegak }
\end{aligned}
$$

\section{HASIL DAN PEMBAHASAN}

\section{Ukuran Utama Kapal}

Dari hasil pengukuran pada kapal Aldeis menunjukkan bahwa panjang total kapal adalah $15,50 \mathrm{~m}$, lebar $2,80 \mathrm{~m}$ dan untuk dalam kapal 1,10 m. Selanjutnya data ukuran utama kapal disajikan pada Tabel 1.

Dari nilai-nilai perbandingan yang diperoleh, dapat dikatakan bahwa kapalkapal Pole and Line kecil yang berpangkalan di Pelabuhan Perikanan Aertembaga Bitung memiliki perbandingan yang sesuai untuk panjang dan lebar dan hal ini memberikan pengaruh yang baik terhadap tahanan kapal. Tahanan yang terjadi pada saat kapal berlayar berkurang sehingga dapat meningkatkan kecepatan kapal. 
Perbandingan panjang dan dalam kapal memiliki nilai yang besar ini memberi pengaruh terhadap kekuatan memanjang kapal, sehingga kapal tidak mudah patah pada saat mendapatkan gaya-gaya dari luar yang bekerja mempengaruhi kekuatan memanjang dari kapal tersebut.

Tabel 1. Ukuran utama kapal Aldeis dan perbandingan ukuran utama.

\begin{tabular}{ccccccc}
\hline $\begin{array}{c}\text { Sampel } \\
\text { Kapal }\end{array}$ & $\mathbf{L}(\mathbf{m})$ & $\mathbf{B}(\mathbf{m})$ & $\mathbf{D}(\mathbf{m})$ & $\mathrm{L} / \mathbf{B}$ & $\mathrm{L} / \mathbf{D}$ & $\mathbf{B} / \mathbf{D}$ \\
\hline Aldeis & 15,50 & 2,80 & 1,10 & 5,54 & 14,09 & $2,55^{*}$
\end{tabular}

\section{Koefisien Bentuk Kapal}

Koefisien bentuk kapal merupakan ukuran yang dapat menggambarkan bentuk kapal menyangkut kemontokan dan kelangsingan bentuk lambung kapal tersebut pada benaman kolom air. Hasil penelitian yang dilakukan pada kapal Aldeis, diperoleh hasil seperti yang ditampilkan pada Tabel 2 .

Tabel 2. Koefisien bentuk kapal Aldeis.

\begin{tabular}{cllll}
\hline Sampel Kapal & $\mathbf{C b}$ & $\mathbf{C p}$ & $\mathbf{C} \otimes$ & $\mathbf{C w}$ \\
\hline Aldeis & 0,54 & 0,73 & 0,74 & $0,79^{*}$ \\
\hline
\end{tabular}

Nilai koefisien balok pada Tabel 2 menunjukkan bahwa volume benaman kapal Aldeis dalam bentuk balok 0,54, ini mengartikan bahwa benaman kapal adalab $54 \%$ dari volume kapal dalam bentuk bajok. Hal ini juga menjelaskan bahwa kápal tersebut bentuk lambungnya langsing yang menguntungkan dalam hak kecepatan kapal.

Nilai koefisien perismatik kapal Aldeis dari hasil perhitungan diperoleh bahwa luas bidang penampang melintang tengah kapal 0,73 . Nilai ini menunjukkan bahwa perbandingan antara volume kapal dibagi dengan perkalian antara bagian tengah kapal secara memanjang sebesar $73 \%$, artinya bahwa kapal Aldeis melebar pada bagian buritan.

2. Nilai penampang tengah kapal Alders yaitu 0,74 . Hal ini menunjukkan bahwa luas bidang penampang melintang tengah kapal Aldeis $74 \%$, yang berarti bahwa kapal Aldeis memiliki bentuk lambung yang relatif mendekati huruf $\mathrm{V}$. Hal ini dapat mempengaruhi kecepatan kapal, dimana tahanannya relatif rendah sehingga meningkatkan kecepatan.

Nilai koefisien bidang airnya 0,79. Hal ini menunjukkan bahwa kapal Aldeis memiliki bentuk penampang garis air yang mendekati ke bentuk empat persegi, sehingga meningkatkan stabilitas kapal.

Dari hasil penelitian dan dibandingkan dengan penelitian sebelumnya terlihat bahwa para pengrajin kapal telah memperhitungkan kecepatan kapal dimana bentuk lambung kapal adalah langsing serta bentuk penampang melintang kapal mendekati huruf $\mathrm{V}$ dimana sangat menguntungkan pada kecepatan kapal.

Jika dilihat dari koefisien prismatik dan koefisien bidang air terlihat bahwa para pengrajin sangat mengutamakan kestabilan kapal dan hal ini dibuktikán dengan nilai koefisien prismatik dan koefisien bidang air yang besar yang menyebabkan bentuk kapal melebar pada bagian buritan kapal dan koefisien bidang áir yang hampir berbentuk empat persigi dimana sangat menguntungkan padă kestabilan kapal.

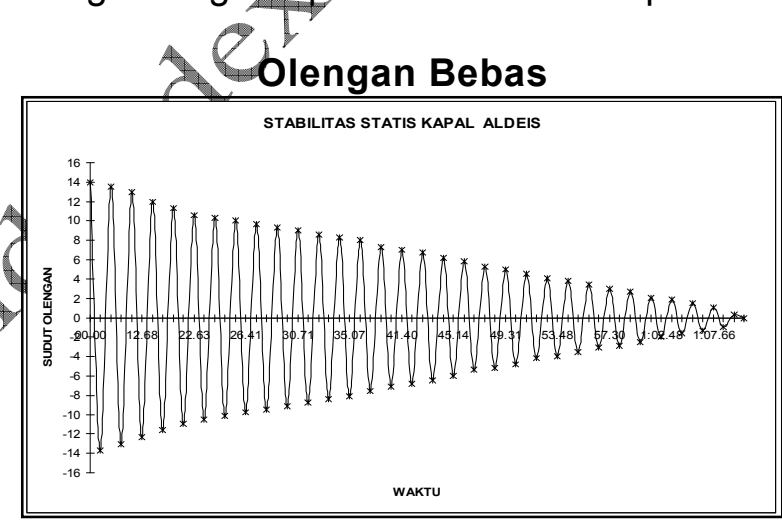

Gambar 1. Olengan bebas kapal Aldeis.

Data yang ditampilkan pada Gambar 1 ini merupakan data olengan bebas yang terjadi pada Kapal Aldeis, dimana sudut bentukan yang terjadi paling maksimum pada kapal ini adalah $14^{\circ}$. Sumbu $X$ menyatakan waktu olengan dan sumbu $Y$ menyatakan besar sudut oleng yang terbentuk selama waktu t dari grafik ini bisa dilihat bahwa penurunan sudut oleng yang terjadi pada Aldeis adalah lambat.

Gambar 2 menjelaskan kurva stabilitas statis dari kapal tipe small pole and liner Aldeis sumbu $X$ adalah sudut kemiringan dan sumbu $Y$ adalah jarak lengan penegak. Gambar ini menjelaskan pula bahwa kapal pada saat kondisi kosong memiliki olengan maksimum hingga pada kemiringan kapal di bawah $14^{\circ}$, saat lengan penegak berada pada jarak $0,20 \mathrm{~m}$, dengan 
nilai GM 0,8583 m ini berarti bahwa Aldeis tidaklah terlalu stabil.

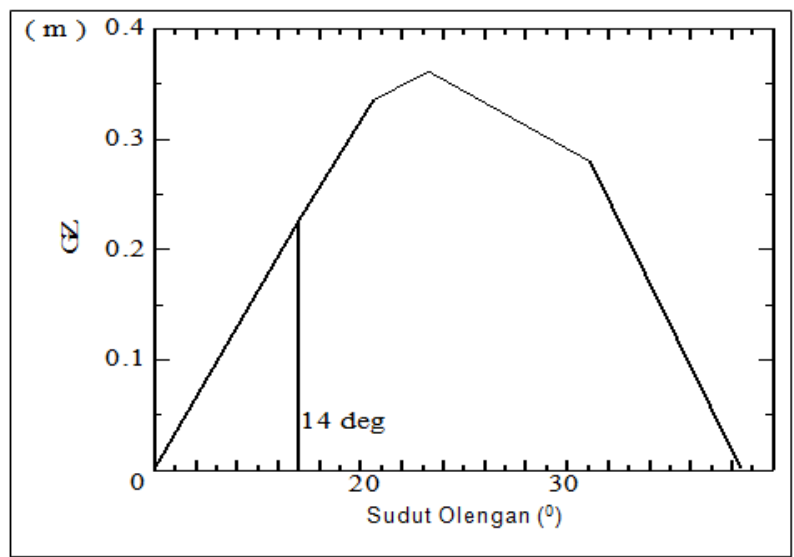

Gambar 2. Kurva stabilitas statis kapal Aldeis.

\section{KESIMPULAN}

Dari hasil penelitian tentang stabilitas statis kapal pole and line KM Aldeis ditarik kesimpulan sebagai berikut:

- Kapal Aldeis mempunyai nilai perbandingan ukuran utama kapal yang relatif baik.

- Kapal Aldeis memiliki bentuk yang cenderung berbentuk $\mathrm{V}$, tidak montok yang mempengaruhi kecepatan Kapal.

- Berdasarkan sudut capzising yang di. peroleh kapal Aldeis maka kapal ini tidaklah terlalu stabil.

\section{DAFTAR PUSTAKA}

Ayodhyoa, A.U. 1972. Fishing Boat. Corespondence Course Centre. IPB. Bogor. $66 \mathrm{P}$

Ariyanto. 1986. Prosedur Penelitian Suatu Pendekatan Praktis. Bina Aksara. 53 Hal.

Atwood, E.L.O.B.E dan Pengelly, H.S. C.B. 1967. Theoritical Naval Architecture. Eongmans. Great Britain.

Dalzell, J.F., 1978. A Note On The Form of Ship Roll Dumping. Journal of Ship Research 22 No. 3 pp. 1978-1985.
Handryanto, 1982. Pembuatan Gill Net 14,5 GT di PT. M. Jusdi. Tegal. Jawa Tengah. Karya IImiah. Fakultas Perikanan. IPB. Bogor. $134 \mathrm{Hal}$.

Hind, J.A. 1967. Trim and Stability of Fishing Vessel. Fishing News (Ltd. London. $120 \mathrm{P}$.

Karman, A. 1996. Pengaruh ukuran luas sirip terhadap stabilitas model kapal tipe lambut. Skripsi Fakultas Perikanañ dan IImu Kelautan. UNSRAT. Mdo. $28 \mathrm{HaL}$

Kok, H.G.M. 1983. Bangunah-Kapal. Martech. 149 Hal.

Lester, A.P. 1985. Merchant Ship stability. Butter worth and Co. London 502 P.

Mandagi, I.F., 2003. Studi Tentang Penurunan Sudut Oleng (Roll Dumping) Pada Kapal Kukat Cincin di Pesisir Bitung danł Bunaken Propinsi Sulawesi Utara. Thesis. Program Pascasarjana. UNSRA Manado. $46 \mathrm{Hal}$.

Masengl, K.W.A., 1992. Studies On The Characteristic of A Small Fishing Boat From The Viewpoint Of Seakeeping Quality. Graduate School Of Marine Sience and Engineering. Nagasaki University.

Muckle, W. 1978. Naval Architercture of Marine Engineers. New Butterword and co. $407 \mathrm{P}$.

Nomura, M and T. Yamazaki. 1977. Fishing Techniques I. JICA. Tokyo. 206 P.

Santoso, I. G.M. dan J.JH Suyono. 1983. Teori Bangunan Kapal. Direktorat Pendidikan menengah Kejuruan. Depdikbud. Jakarta.

Suryabrata, J. 1987. Metode Penelitian. CV. Rajawali. Jakarta. $126 \mathrm{Hal}$.

Undang-undang Republik Indonesia No. 21 Tahun 1992. Tentang Pelayaran. Bab I. Ketentuan Umum Pasal 1 Ayat 2. 